\title{
Spatio-Temporal Dynamics of Arabica Coffee Berry Disease Caused by Colletotrichum kahawae on a Plot Scale
}

\author{
J. A. Mouen Bedimo, IRAD, Station Polyvalente de Foumbot, BP 665 Bafoussam Cameroon; D. Bieysse, CIRAD- \\ INRA-ENSAM, UMR BGPI, Campus International de Baillarguet, TA41/k, 34398 Montpellier Cedex 5 France; \\ C. Cilas, CIRAD-CP, UPR Maîtrise des Bioagresseurs de pérennes, Avenue Agropolis, TA80/02 34398 Montpellier \\ Cedex 5 France; and J. L. Nottéghem, CIRAD-INRA-ENSAM, UMR BGPI, Campus International de Baillarguet, \\ TA41/k, 34398 Montpellier Cedex 5 France
}

\begin{abstract}
Mouen Bedimo, J. A., Bieysse, D., Cilas, C., and Nottéghem, J. L. 2007. Spatio-temporal dynamics of arabica coffee berry disease caused by Colletotrichum kahawae on a plot scale. Plant Dis. 91:1229-1236.

Coffee berry disease (CBD) is caused by Colletotrichum kahawae. This pathogen only attacks green berries; it causes cherry rot and premature fruit fall. The disease leads to major harvest losses in the western highland region of Cameroon. The origin of the primary inoculum and the beginning of epidemics are unknown. The interactions between the pathogen and its host were studied at locations where CBD was known to cause severe disease. The disease was monitored weekly in uniform plots of adjacent coffee trees at Santa $(1,750 \mathrm{~m})$ in 2003 and 2004 and Bafou $(1,820 \mathrm{~m})$ in 2004 and 2005. The logistic model provided good fit of the epidemic's temporal dynamics. The spatial distribution of CBD over time indicated that plants in a plot were contaminated stepwise from the first infected coffee tree. An analysis of semi-variograms and the disease dispersal maps obtained by kriging revealed primary infection foci at both sites. They were observed from the 8th to the 10th week after flowering at Bafou and from the 11th to the 13th week at Santa. CBD affected the entire plots 3 weeks after the foci first appeared. These results suggest that inoculum from previous epidemics survives at points in the initial foci in a coffee plantation.
\end{abstract}

In Cameroon, arabica coffee is grown on small family farms in the western highlands $(1,000$ to $2,000 \mathrm{~m})$. The climate in the region is characterized by a 4 - to 5month dry season (November to March) and a monomodal rainy season lasting 7 to 8 months (March to October). That climate, which is typical of tropical high altitude regions, is favorable to synchronous flowering of plants triggered by the first rainy spells, in mid-March. Fruit development takes place over a season lasting 6 to 7 months. Coffee berry disease (CBD), caused by Colletotrichum kahawae Waller \& Bridge, is the main cause of yield loss in arabica coffee in the Cameroon. After harvesting, at the beginning of the dry season, the absence of berries for a period of 5 months raises questions about pathogen survival and the means by which epidemics begin. Without fungicide applications, losses caused to C. kahawae can reach $90 \%$ on some small holdings at high altitudes $(>1,600$ m) (7).

Corresponding author: C. Cilas

E-mail: christian.cilas@ cirad.fr

Accepted for publication 20 February 2007.

doi:10.1094/PDIS-91-10-1229

(c) 2007 The American Phytopathological Society
Epidemics caused by fungi of the genus Colletotrichum occur frequently on perennial crops in the tropics. Epidemics may be caused by ubiquitous pathogens, such as $C$. gloeosporioides on mango $(3,13,14)$, or by what is now $C$. acutatum on citrus (11), in which the pathogen can attack several aerial tissues of those species. For those diseases, tissues susceptible to the pathogen are present throughout the year on the host plant. For other diseases, the pathogen attacks the host only during a certain stage of its development, and epidemics develop over a short period of the plant's annual cycle. One such pathosystem is coffee berry disease (CBD) caused by Colletotrichum kahawae Waller \& Bridge sp. nov. (33). As with other species of Colletotrichum, conidia are produced in acervuli and appear as an orange-colored, mucilaginous mass. Flower buds, branch bark, and mummified berries are considered to be potential sources of primary inoculum $(21,24,29)$. At the start of the rainy season (March to October), C. kahawae resumes its parasitic activity, infecting young fruit (the "pin head" stage) 4 to 6 weeks postflowering. The first symptoms are detected typically on 8- to 10-week-old fruits and appear as dark, sunken lesions that can expand and coalesce to affect the entire fruit. Some infected berries remain attached to branches and serve as a secondary source of inoculum. Several pathogen development cycles may occur up to the 25 th week of fruit development, when berries develop ontogenic resistance, coinciding with the beginning of fruit endocarp hardening $(21,29)$.

CBD severity is highly dependent upon climatic factors, particularly temperature, rainfall, and humidity. Rain is necessary for the dispersal of conidia of Colletotrichum spp. $(16,18,23)$. Optimum temperatures for conidium germination and mycelium growth are 20 to $22^{\circ} \mathrm{C}$ for $C$. kahawae on coffee $(21,29)$. Appressorium formation occurs at the same temperatures and at relative humidity approaching $100 \%$ $(6,12,17)$. Climatic conditions conducive to $C$. kahawae typically occur at high elevations $(>1,600 \mathrm{~m})$; disease incidence is minimal below $1,000 \mathrm{~m}$. Agricultural practices may also influence disease severity $(19,26)$.

Currently, CBD is managed through host resistance (8), cultural practices, and chemical control (21). However, these management practices could be used more efficiently as part of an IPM strategy that can be applied by producers of arabica coffee. Such an approach requires prior knowledge of the host/parasite/environment interactions that govern disease development. We therefore carried out spatio-temporal monitoring of the disease, in order to gain a clearer understanding of how epidemics developed in a high altitude region with high disease pressure. The study was undertaken at two sites with contrasting agro-ecological conditions. The spatial dynamics of the disease within plots were analyzed and the type of dispersal was identified to help optimize control methods.

\section{MATERIALS AND METHODS}

Characterization of plots. Studies to examine the spatio-temporal effects of CBD were conducted at two locations in the Cameroon, Bafou $\left(05^{\circ} 33.540 \mathrm{~N}\right.$, $10^{\circ} 04.520 \mathrm{E}, 1,820 \mathrm{~m}$ elevation) and Santa $\left(05^{\circ} 47.190 \mathrm{~N}, 10^{\circ} 09.672 \mathrm{E}, 1,750 \mathrm{~m}\right.$ elevation). At each site, a uniform plot grown without shade and without intercrops was chosen. The plots, measuring approximately $1,000 \mathrm{~m}^{2}$, contained 58 coffee trees at Santa and 67 at Bafou. Each coffee tree was identified spatially by its coordinates and an identification number. The coffee 
trees at Santa were about 50 years old and were pruned to umbrella type architecture. At Bafou, the trees were around 20 years old with a single stem and were pruned to a pyramid. Coffee plants at both locations were of the cultivar Jamaica, which is highly susceptible to CBD. The coffee trees were spaced $3 \times 2.5 \mathrm{~m}$ apart and were maintained by pruning to remove dead branches, suckers, and mummified berries. They were fertilized after each fruit-set with mineral fertilizer (N-P-K: 20-10-10, ADER-Cameroon) at a rate of $200 \mathrm{~g}$ per plant. Two annual applications of glyphosate (Round-Up; Monsanto) at 2.4 liters/ha were made to control weeds. This study was conducted on the same trees for two consecutive years: from 2003 to 2004 at Santa and from 2004 to 2005 at Bafou.

Assessment of disease incidence and losses. Three plagiotropic branches, located in the upper, middle, and lower sections of the coffee trees, were marked at the pin head stage. The following data were obtained on each branch: (i) total number of berries, (ii) number of new diseased berries, and (iii) number of old diseased berries. Each new diseased berry was marked with a label to avoid duplicate counts in subsequent weeks. Each year, the observations were systematically started from the 6th week after flowering, and ended around the 25th week. For weekly assessment, the cumulative percentage of diseased berries (Pdis) per tree was determined as:

$$
\text { Pdis }=\frac{\sum_{n=1}^{25} N d b_{n}}{\operatorname{Tot}_{1}} \times 100
$$

where $\left(N d b_{n}\right)=$ the sum of diseased new berries from the first to the $n$th observation, and $T o t B_{1}=$ the total number of berries counted on the first observation.

Daily rainfall was recorded during the entire experimental period in each site. These were used to compute weekly cumulative rainfall.

Statistical analyses. The general linear model (GLM) was used to carry out an analysis of variance to determine the effect of berry position on the trees (upper, middle, and lower sections) on the percentage of diseased berries at the end of each year. For this analysis, each coffee tree was considered as an experimental unit; the number of replicates thus corresponded to the number of individuals in the plot (58 at Santa and 67 at Bafou). All data underwent $\operatorname{arcsine} \sqrt{ } x$ transformation to normalize the variance. Descriptive maps of spatial distribution of the disease were also produced from the cumulated percentages of diseased berries over time.

Temporal analysis. Disease progression over time was examined by modeling data with nonlinear regressions of the polynomial, sigmoidal, and miscellaneous model families. The best possible curve fit was then selected based on standard errors (S) and correlation coefficients $\left(R^{2}\right)$. The logistic regressions of the sigmoidal family model were defined by the formula: $Y=$ $K /[1+B \exp (-r t)]$, with $Y$ and $t$, respectively, representing the cumulated percentage of infected berries and the number of weeks after flowering. The coefficients $K$, $r$, and $B$, respectively, represented the maximum disease level, the rate parameter, and the constant term of the model. The rate of change of disease level $Y$ at time $t$ was determined using the derivative $Y^{\prime}(t)=$ $[r K B \exp (-r t)] /\left[(1+B \exp (-r t)]^{2}\right.$ in which $B$ $=\left(K-Y_{0}\right) / Y_{0}, Y_{0}$ being the initial disease level (20). The duration of the exponential period and the maximum rate of disease spread were determined by the formulas used for cocoa pod growth modeling by Berry and Cilas (5): $K r / 4$ for the maximum rate of disease spread and $\ln (B) / r$ for its exponential phase.

Spatial analysis. Spatial correlations between coffee trees were determined by analyzing semi-variograms, the principle of which is to measure the variability existing on average between the points $z_{i}$ and $z_{i+h}$ lying $h$ apart inside a plot. Statistically, semivariance is an autocorrelation defined by the function:

$$
\Upsilon(h)=[1 / 2 N(h)] \sum\left[z_{i}-z_{i+h}\right]^{2}
$$

where $\Upsilon(h)$, the semivariance for interval distance class $h$, is half the average of the sum of square differences between the percentage of infected berries for $N$ sample pairs of trees, with the lag interval $h . z_{i}$ is the percentage of infected berries measured for sample trees at point $i$, and $z_{i+h}$ is the percentage measured for sample trees at point $i+h$. The variogram is a model for average semivariances of all possible interval classes plotted against their corresponding lag distances. The data were auto-fitted to the exponential, spherical, and Gaussian isotropic model variograms to analyze the multidirectional spatial dependence between coffee trees. These models are described by three parameters: (i) the separation distance or the range $(A)$ over which the spatial dependence is apparent, (ii) the $y$-intercept of the model or the nugget variance $\left(C_{0}\right)$, which indicates the discontinuity of the variogram at lag zero, and (iii) the sill $\left(C+C_{0}\right)$, which is the model asymptote. The residual sums of squares (RSS), the $R^{2}$ coefficient, and the proportion of $C /\left(C_{0}+C\right)$ are the statistics mainly used for interpreting the validity of the variogram model (Geostatistics for the Environmental Sciences. Gamma Design Software, LLC, Plainwell, MI, USA). The RSS provides an exact measure of how well the model fits the variogram data; the lower the reduced sums of squares, the better the model fits. The $R^{2}$ coefficient provides an indication of how well the model fits the variogram data, but it is not as sensitive or robust as RSS for best-fit calculations. The proportion of $C /\left(C_{0}+C\right)$ provides a measure of the proportion of sample variance $\left(C_{0}+C\right)$ that is explained by spatially structured variance $C$. This value will be 1 for a variogram with no nugget variance (where the curve passes through the origin). It will be 0 where there is no spatially dependent variation at the range specified. $C_{0}$ (the nugget variance) is the $y$-intercept of the model, and $C_{0}+C$ (the sill) is the model asymptote.

Kriging analysis was used to localize foci on the experimental plot. Kriging is a nearest-neighbor interpolation technique in which the estimated disease level at a given tree location is a weighted moving average of best estimates to minimize local area variance (Geostatistics for the Environmental Sciences). It is the best linear unbiased estimator based on prior selection of a variogram. Kriging can only be performed for variograms showing spatial dependence between trees.

The analysis of variance and the descriptive maps of disease spatial distribution were carried out with SAS software (Version 9.0, SAS Institute Inc., Cary, NC). The analysis of nonlinear regressions was carried out with CurveExpert software (D. Hyams, Starkville, MS, USA). Semivariogram and kriging analyses were carried out with $\mathrm{GS}^{+}$(Gamma Design Software).

\section{RESULTS}

Incidence of CBD depending on branch position on the coffee tree. The total number of berries differed each year, irrespective of the site. It was relatively high in 2004 at both sites, with an average of 48 berries per branch at Bafou and 66 berries at Santa. The initial number of berries was small in 2003 at Santa and in 2005 at Bafou (Table 1).

At Santa, the percentage of infected berries was estimated to be around $40 \%$ in each of the two study years (Fig. 1A and B). However, at Bafou, CBD incidence varied significantly $(P<0.0001)$ from one year to the next. It was estimated at around $30 \%$ of diseased berries in 2004 and $20 \%$ in 2005 (Fig. 1C and D). There were no differences between coffee tree branches at Santa (Table 1), but a significant interaction between coffee tree branches and production years at Bafou. In 2004, the highest incidence was found in the upper branches. Disease rates were constant on all the branches in 2005 (Table 1).

Spatio-temporal dynamics of the disease. Temporal dynamics. The best fits for temporal disease spread were obtained with the logistic and Morgan-MercerFlodin (MMF) models, both belonging to the sigmoidal model family (Table 2 ). The logistic model was the most suitable to explain the temporal disease spread at both sites, although the 2004 data were well fitted by the MMF model at Santa (Table 2). At Santa, the infection spread rapidly between the 10th and 20th weeks after flowering (Fig. 1A and B). The maximum 
rate of disease spread was estimated at around $6 \%$ (diseased new berries per week) in 2003 and 5\% in 2004 (Table 3). The rate of spread was slower at Bafou, with around $4 \%$ in 2004 and $3 \%$ in 2005. The duration of the disease exponential phase was estimated at 13 to 15 weeks at Santa; and between 10 and 13 weeks at Bafou. In 2004, the rainfall received during the period of exponential disease spread was higher at Santa than at Bafou (Fig. 2).

The cumulative percentage of berries infected during the asymptotic phase of the disease was higher and more stable at Santa than at Bafou, whatever the year. At Santa, this disease period was observed around the 20th week in 2003 and around the 25th week in 2004 (Fig. 1A and B). At Bafou, it occurred around the 20th week for both years (Fig. 1C and D).

Spatial dynamics at different stages of the epidemic. At the start of the epidemic, symptoms were observed on trees that were either isolated or in small clusters (Fig. 3A and B). Semi-variogram analysis indicated an isotropic type of distribution,

Table 1. Number of berries at beginning of season and disease rate at both sites depending on branch position for coffee berry disease for the different years of observations

\begin{tabular}{lllclcc}
\hline & & \multicolumn{2}{c}{ Bafou } & & \multicolumn{2}{c}{ Santa } \\
\cline { 3 - 4 } Year & Branches & $\begin{array}{c}\text { Total number } \\
\text { of berries }\end{array}$ & $\begin{array}{c}\text { \% Infected } \\
\text { berries }\end{array}$ & & $\begin{array}{c}\text { Total number } \\
\text { of berries }\end{array}$ & $\begin{array}{c}\text { \% Infected } \\
\text { berries }\end{array}$ \\
\hline 2003 & Upper & $\ldots$ & $\ldots$ & & $32.82 \mathrm{a}$ & $43.04 \mathrm{a}$ \\
& Middle & $\ldots$ & $\ldots$ & & $40.22 \mathrm{a}$ & $35.87 \mathrm{a}$ \\
& Lower & $\ldots$ & $\ldots$ & & $36.49 \mathrm{a}$ & $33.21 \mathrm{a}$ \\
2004 & Upper & $50.14 \mathrm{a}^{\mathrm{z}}$ & $33.71 \mathrm{a}$ & & $68.13 \mathrm{a}$ & $42.46 \mathrm{a}$ \\
& Middle & $48.09 \mathrm{a}$ & $27.32 \mathrm{~b}$ & & $65.34 \mathrm{a}$ & $38.95 \mathrm{a}$ \\
& Lower & $47.33 \mathrm{a}$ & $22.88 \mathrm{~b}$ & & $64.61 \mathrm{a}$ & $37.28 \mathrm{a}$ \\
& Upper & $27.62 \mathrm{a}$ & $15.24 \mathrm{a}$ & & $\ldots$ & $\ldots$ \\
& Middle & $25.26 \mathrm{a}$ & $19.72 \mathrm{a}$ & & $\ldots$ & $\ldots$ \\
& Lower & $21.12 \mathrm{a}$ & $17.65 \mathrm{a}$ & & $\ldots$ & $\ldots$ \\
\hline
\end{tabular}

${ }^{\mathrm{z}}$ Means were separated by the Student-Newman-Keuls test at $P=0.05$.

indicating that CBD did not spread in a preferential direction. In 2003 at Santa and 2004 at Bafou, semi-variogram analysis revealed a pure nugget effect (no spatial dependency between the coffee trees) at the start of the disease, and beyond the 10th and 13th week at Bafou and Santa, respectively (Table 4). Spatial correlation among infected coffee trees was observed between the 8th and 10th weeks at Bafou, and the 11th and 13th weeks at Santa. For both sites, the range decreased over time and the sill increased. The range varied from 2.64 to $3.6 \mathrm{~m}$ at Santa, meaning that the spatial dependence can only be observed between immediate neighboring trees. The biggest range at Bafou was 8.37 $\mathrm{m}$, indicating spatial correlations up to three trees away. The first two semivariograms were spherical at Santa (Fig. $4 \mathrm{~A}$ and $\mathrm{B}$ ), and the last one was Gaussian (Fig. 4C). At Bafou, all of them were Gaussian (Fig. 5A to C). These curves showed that CBD spread was stepwise at Santa; in contrast, the disease could spread to coffee trees that were more than two units away at Bafou. However, an analysis of the data obtained at Santa revealed large residual errors (RSS) and weak coefficients of determination $\left(R^{2}\right)$. On the other hand, it revealed very small residual errors

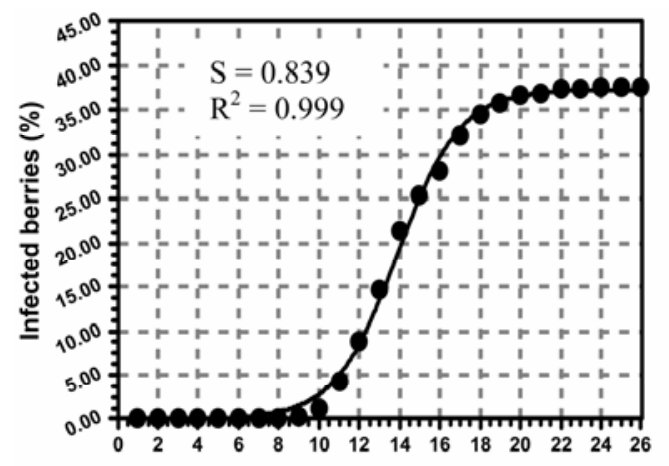

Age of the berries (weeks)

A) Santa : 2003

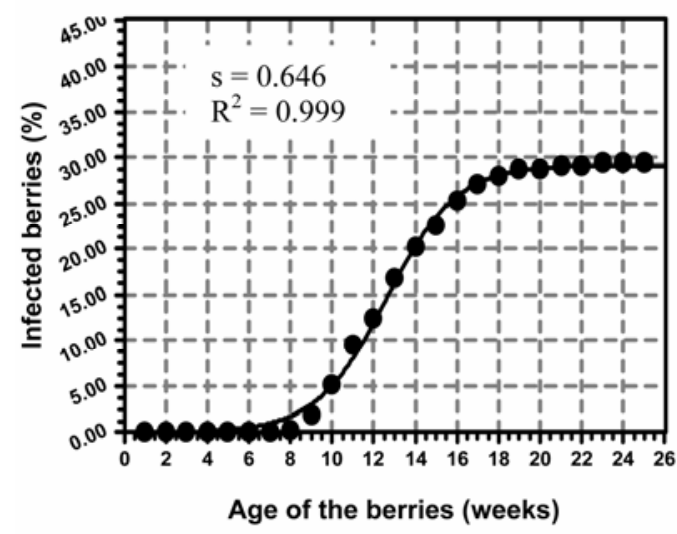

C) Bafou : 2004

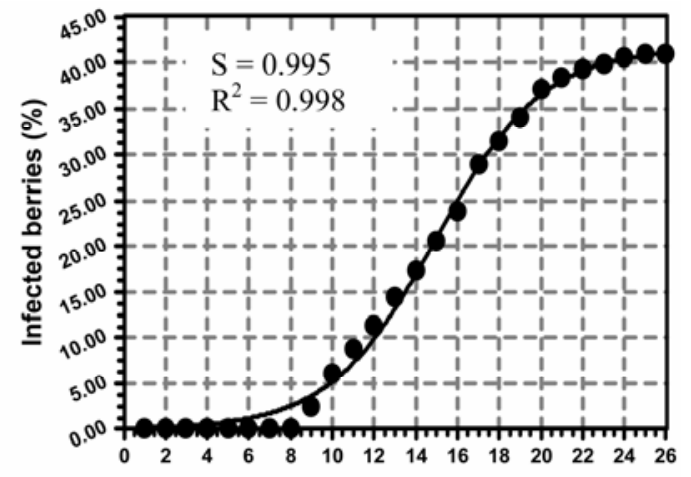

Age of the berries (weeks)

B) Santa : 2004

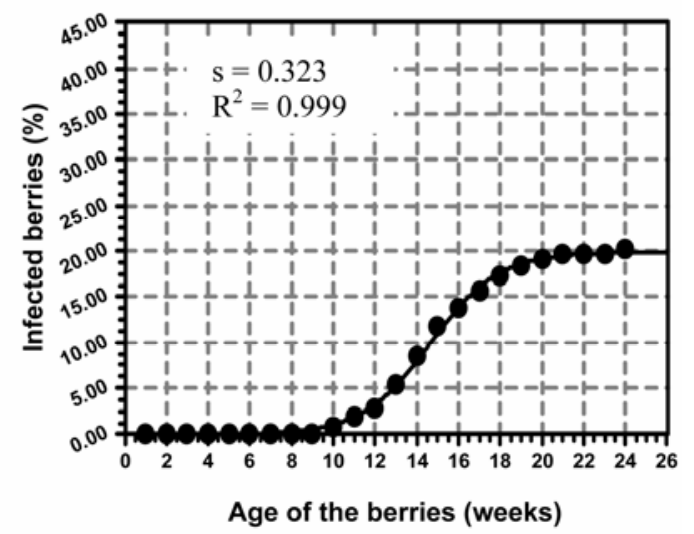

D) Bafou :2005

Fig. 1. Logistic fit curves for coffee berry disease temporal spread at Santa and Bafou. $\bullet=$ true curve, and $\bullet=$ theoretical curve. 
and high coefficients of determination $\left(R^{2}\right.$ $>0.80$ ) at Bafou (Table 4).

In the second year of observations (2004 at Santa and 2005 at Bafou), the infection foci were not detected at Santa, unlike at Bafou, where they were observed from the 10 th to the 24th week. However, the foci obtained at Bafou in 2005 were dependent on experimental bias caused by around 10 coffee trees without berries. At that site, the semi-variogram displayed morphological diversity over time. It was exponential in the 10th week, with strong discontinuity at the origin (Fig. 5D), thereby suggesting the existence of considerable irregularity in infection levels at the time the first symptoms appeared. It was Gaussian between the 11th and 24th week (Fig. 5E and F). At Santa, the infection foci were only observed in 2003, as shown on the maps in Figure 6 . They were obtained every year at Bafou (Fig. 7). Over the two successive years of observations, a focus located at the same spot was detected at that site (Fig. 7A and D).

\section{DISCUSSION}

In several countries where CBD exists, it has been reported that infection severity increases with the height above sea level, as CBD is favored by cooler temperatures $(16,21,26)$. However, in our study, disease development was less at the higher altitude site. It is likely that the variation in severity came from the different rainfall at the two sites. In fact, in pathosystems where pathogen propagation mostly occurs through splashing, rainfall intensity ensures good dispersal of inoculum on the host plant, such as is the case with Gibberella zeae on wheat (25) or Botryosphaeria dothidea on pistachio (2). At Santa, CBD severity was uniform on all coffee tree branches, irrespective of the observation year. On the other hand, at Bafou in 2004, coffee tree branches were attacked in line with an ascending severity gradient. Conidia were generally dispersed from the top to the bottom of the trees $(1,32)$ as they were transported by gravity and raindrops. The disease should therefore have been worse on the lower branches, as in the case of citrus where C. gloeosporioides (now C. acutatum) infections develop along a descending gradient (1). But, it is likely that C. kahawae infection by rainfall was less effective on the berries of the lower branches due to a possible barrier effect of the branches in the canopy. In addition, since infection was more severe on the fruits on the upper branches rather than on the lower branches, coffee trees in the umbrella form at Santa, where most of the berries are concentrated toward the canopy, were more severely attacked by CBD than those at Bafou. Little is known about the role of coffee tree architecture on CBD development. We feel such a study is necessary to assess the spatial distribution of the disease on a coffee tree scale, and to determine the specific impact of rainfall on its distribution.

Table 3. Characteristics of coffee berry disease epidemics observed at both sites

\begin{tabular}{|c|c|c|c|c|c|}
\hline \multirow[b]{2}{*}{ Site } & \multicolumn{3}{|c|}{ Logistic model parameters } & \multirow{2}{*}{$\begin{array}{c}\text { Slope }^{y} \\
(\%)\end{array}$} & \multirow{2}{*}{$\begin{array}{c}\text { Duration }^{\mathrm{z}} \\
\text { (weeks) }\end{array}$} \\
\hline & $K$ & $B$ & $r$ & & \\
\hline \multicolumn{6}{|l|}{ Santa } \\
\hline 2003 & 37.32 & 4050.02 & 0.65 & 6.03 & 13 \\
\hline 2004 & 41.56 & 351.39 & 0.39 & 4.81 & 15 \\
\hline \multicolumn{6}{|l|}{ Bafou } \\
\hline 2004 & 29.22 & 1805.58 & 0.60 & 4.35 & 13 \\
\hline 2005 & 19.88 & 372.49 & 0.61 & 3.06 & 10 \\
\hline
\end{tabular}

y Slope at inflection point.

${ }^{\mathrm{z}}$ Duration of the exponential period.

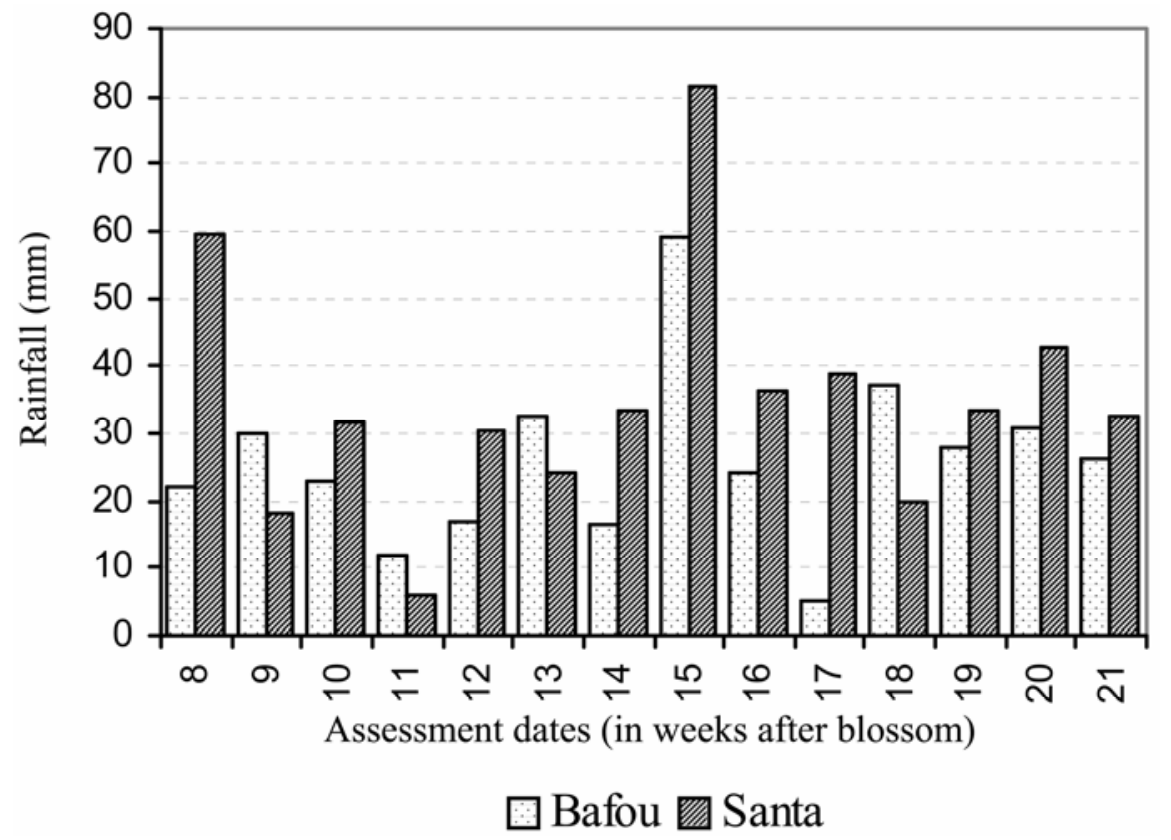

Fig. 2. Weekly cumulative rainfall during the exponential period of disease progression of coffee berry disease.

Table 2. Model functions of temporal progression of coffee berry disease at Santa (2003-2004) and Bafou (2004-2005)

\begin{tabular}{clll}
\hline & & \multicolumn{1}{c}{ Model families } & Miscellaneous \\
\cline { 2 - 4 } Site & Sigmoid & Polynomial & Sinusoidal fit \\
Santa & & & $\left(\mathrm{S}=2.3923 ; R^{2}=0.9908\right)$ \\
2003 & Logistic & 3rd degree polynomial & $18.79+20.83 \mathrm{Cos}(0.17 X+2.18)$ \\
& $\left(\mathrm{S}=0.8390 ; R^{2}=0.9988\right)$ & $\left(\mathrm{S}=2.6928 ; R^{2}=0.9883\right)$ & Sinusoidal fit \\
& $37.32 /\left(1+4050 \mathrm{exp}^{-0.65 X}\right)$ & $9.43-4.63 X+0.51 X^{2}-0.01 X^{3}$ & $\left(\mathrm{~S}=0.9155 ; R^{2}=0.9987\right)$ \\
2004 & Morgan-Mercer-Flodin & 3 rd degree polynomial & $19.85+21.32 \mathrm{Cos}(0.16 X+2.41)$ \\
& $\left(\mathrm{S}=0.8701 ; R^{2}=0.9988\right)$ & $\left(\mathrm{S}=1.1377 ; R^{2}=0.9980\right)$ & \\
Bafou & $\left(-1.6 * 10^{5}+45.56 X^{4.74}\right) /\left(4 * 10^{5}+X^{4.74}\right)$ & $5.39-3.49 X+0.46 X^{2}-0.01 X^{3}$ & Sinusoidal fit \\
2004 & & & $\left(\mathrm{~S}=1.5367 ; R^{2}=0.9938\right)$ \\
& Logistic & 3 rd degree polynomial & $14.49+16.26 \mathrm{Cos}(0.18 X+2.08)$ \\
& $\left(\mathrm{S}=0.6457 ; R^{2}=0.9988\right)$ & $\left(\mathrm{S}=1.7995 ; R^{2}=0.9915\right)$ & Sinusoidal fit \\
2005 & $29.22 /\left(1+1806 \mathrm{exp}^{-0.6 X}\right)$ & $9.05-4.34 X+0.48 X^{2}-0.01 X^{3}$ & $\left(\mathrm{~S}=1.1726 ; R^{2}=0.9918\right)$ \\
& Logistic & 3 rd degree polynomial & $9.44+10.99 \operatorname{Cos}(0.18 X+2.12)$ \\
\hline
\end{tabular}



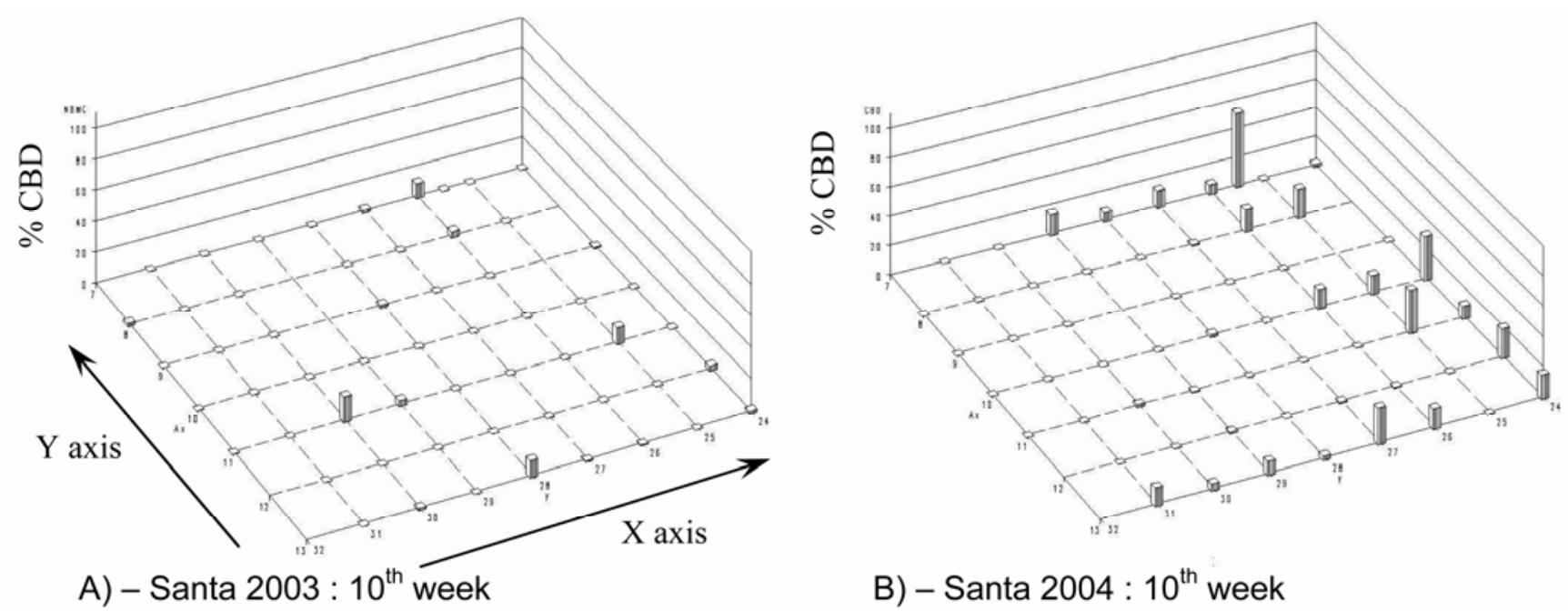

B) - Santa $2004: 10^{\text {th }}$ week
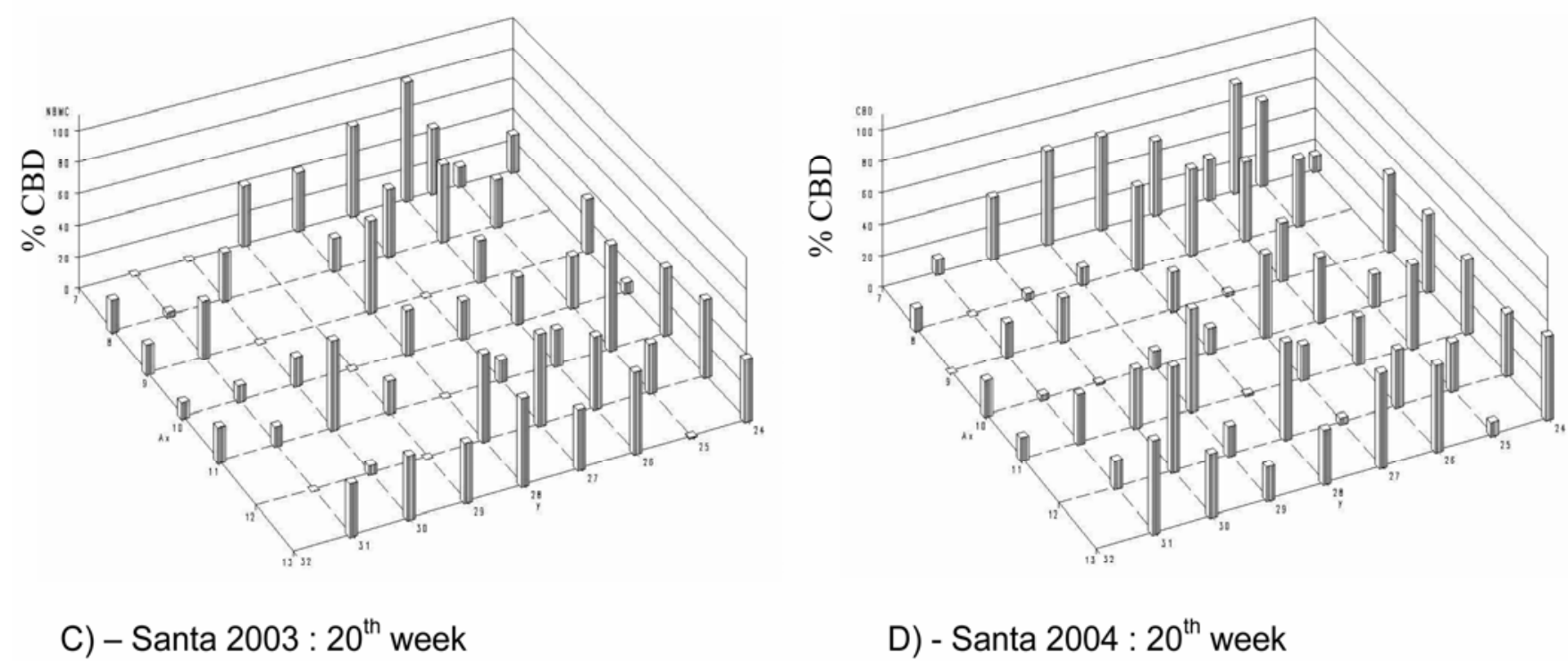

Fig. 3. Spatial distribution of coffee trees affected by coffee berry disease in the 10th and the 20th week after flowering at Santa. Bars indicate cumulated percentage of infected berries, and $\mathrm{x}$ - and $\mathrm{y}$-axes indicate coordinates of each tree on the plot.

Table 4. Characteristics of semi-variograms obtained at Santa (2003 and 2004) and at Bafou (2004 and 2005) for coffee berry disease (CBD)

\begin{tabular}{|c|c|c|c|c|c|c|c|}
\hline Sites & $\begin{array}{c}\text { Berries' age } \\
\text { (weeks) }\end{array}$ & $\begin{array}{c}\text { Range } \\
(A)\end{array}$ & $\begin{array}{c}\text { Sill } \\
\left(C_{0}+C\right)\end{array}$ & $C /\left(C_{0}+C\right)$ & $\mathbf{R S S}^{\mathbf{z}}$ & $R^{2}$ & Model \\
\hline \multicolumn{8}{|l|}{ Santa } \\
\hline \multirow[t]{6}{*}{2003} & 06 to 08 & $\ldots$ & $\ldots$ & $\ldots$ & $\ldots$ & $\ldots$ & No infected berries \\
\hline & 09 to 10 & $\ldots$ & $\ldots$ & 0 & $\ldots$ & $\ldots$ & Pure nugget effect \\
\hline & 11 & 3.60 & 121.1 & 0.999 & 10,447 & 0.18 & Spherical \\
\hline & 12 & 2.73 & 176.0 & 0.999 & 9,658 & 0.16 & Spherical \\
\hline & 13 & 2.64 & 296.3 & 0.934 & 5,943 & 0.62 & Gaussian \\
\hline & 14 to 26 & $\ldots$ & $\ldots$ & 0 & $\ldots$ & $\ldots$ & Pure nugget effect \\
\hline \multirow[t]{2}{*}{2004} & 06 to 08 & $\ldots$ & $\ldots$ & $\ldots$ & $\ldots$ & 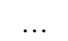 & No infected berries \\
\hline & 09 to 26 & $\ldots$ & $\ldots$ & 0 & $\ldots$ & 0.43 & Pure nugget effect \\
\hline \multicolumn{8}{|l|}{ Bafou } \\
\hline \multirow[t]{5}{*}{2004} & 06 to 07 & & $\ldots$ & & $\ldots$ & & No infected berries \\
\hline & 08 & 8.37 & 0.944 & 0.999 & 0.11 & 0.84 & Gaussian \\
\hline & 09 & 6.69 & 5.876 & 0.998 & 2.63 & 0.92 & Gaussian \\
\hline & 10 & 5.55 & 27.24 & 1 & 21.9 & 0.93 & Gaussian \\
\hline & 11 to 25 & $\ldots$ & $\ldots$ & 0 & $\ldots$ & 0.80 & Pure nugget effect \\
\hline \multirow[t]{4}{*}{2005} & 06 to 09 & & & & $\ldots$ & $\ldots$ & No infected berries \\
\hline & 10 & 11.97 & 2.59 & 0.624 & 0.62 & 0.54 & Exponential** \\
\hline & 11 & 4.35 & 5.674 & 0.998 & 2.08 & 0.81 & Gaussian \\
\hline & 12 to 24 & 3.57 & 10.91 & 0.999 & $\ldots$ & 0.80 & Gaussian \\
\hline
\end{tabular}

${ }^{\mathrm{z}}$ Residual sum of squares. 
At both sites, the best fits for temporal CBD spread were obtained with the logistic model $\left(R^{2} \approx 0.998\right)$. Logistic regressions are highly suited to modeling the temporal dynamics of polycyclic epidemics during which the secondary inoculum is favorable to exponential disease development. They are particularly suitable for pathosystems in which new healthy organs are contaminated gradually during their growth, up to their ontogenic resistance period $(27,28,34)$. At Santa, the rate of disease spread varied each year, probably due to climatic variations, pathogen infection pressure, and fruit receptiveness during their growth. However, the ultimate infection level remained substantially the same over the 2 years. The model parameters $(K, B$, and $r)$ varied depending on the site and year (Table 3 ). They would thus seem to confirm the hypothesis of a considerable influence of mostly random climatic parameters (rainfall, temperatures, wind, etc.) on the temporal spread of CBD.

Various spatial analysis methods have been used by numerous authors to study the regionalization of diseases in plots $(9,10,22,30,31)$. Those methods vary depending on the pathosystems; however, they all have the principle of determining spatial correlations that might exist between plants within the plot $(3,31)$. A study of semi-variograms using geostatistical analyses enabled us to identify CBD infection foci. Sache defined the focus as "the first point of inoculation characterized by a quantity of disease that is far greater than that seen on surrounding plants" (28). Such foci were found at the two sites, in the first year of observations (2003 at Santa and 2004 at Bafou). They appeared 1 to 2 weeks after the first symptoms and became blurred during the exponential phase of the disease, precisely at the time of its maximum spread. In the second year of observations, infection foci were not seen at Santa, unlike at Bafou where they persisted from the start of the disease to

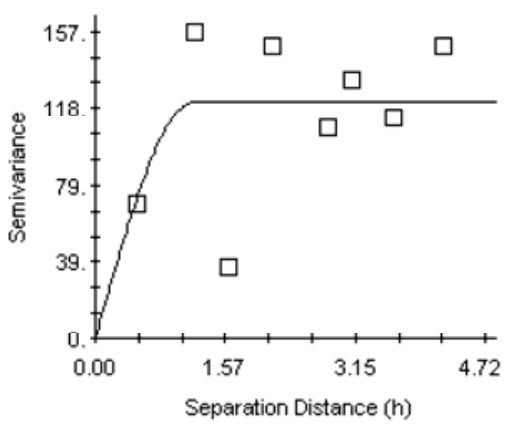

A) Santa $2003: 11^{\text {th }}$ week

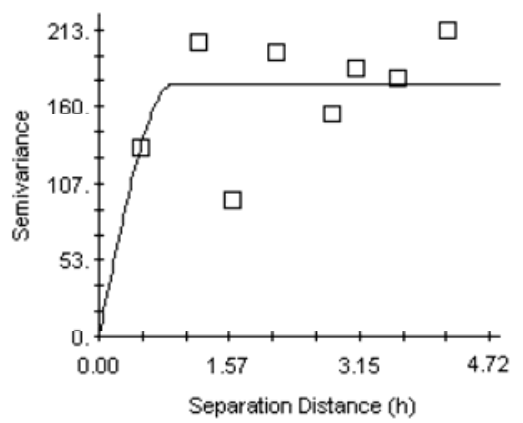

B) Santa $2003: 12^{\text {th }}$ week

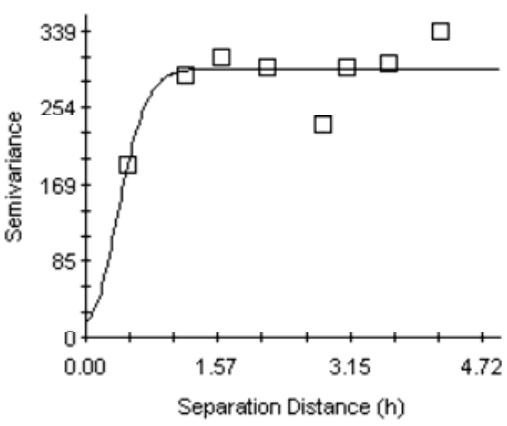

C) Santa $2003: 13^{\text {th }}$ week

Fig. 4. Semi-variograms indicating spatial correlations in the first year of observations of coffee berry disease (2003) at Santa. Lag distances on $\mathrm{x}$-axis are from the model and must be multiplied by $3 \mathrm{~m}$ to obtain the interval in the field.

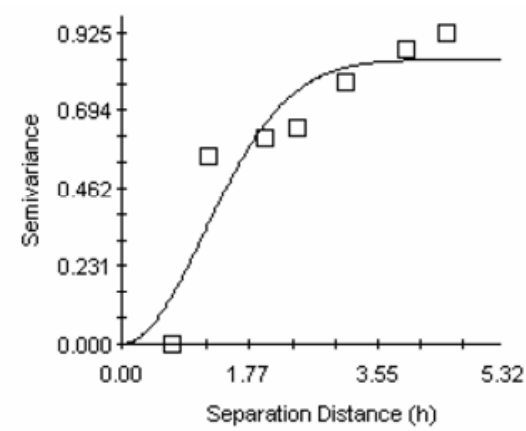

A) Bafou $2004: 8^{\text {th }}$ week

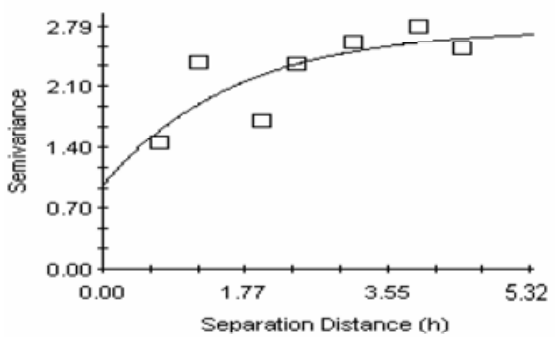

D) Bafou $2005: 10^{\text {th }}$ week

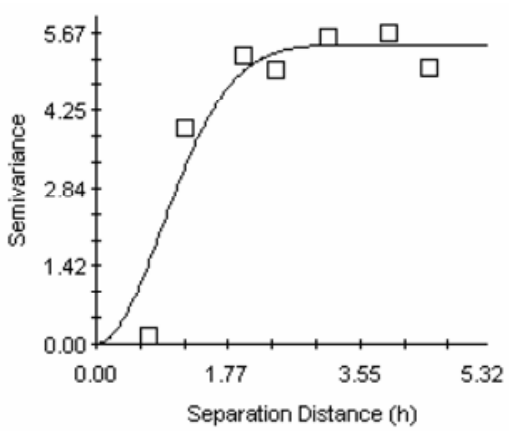

B) Bafou $2004: 9^{\text {th }}$ week

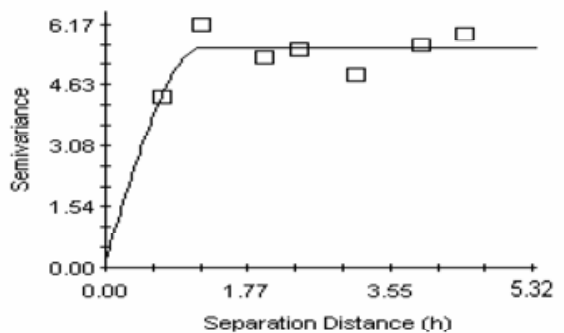

E) Bafou $2005: 11^{\text {th }}$ week

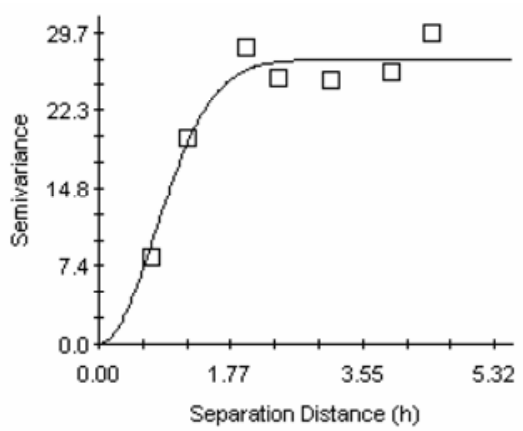

C) Bafou $2004: 10^{\text {th }}$ week

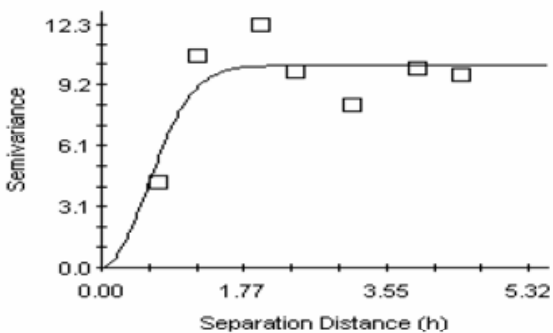

F) Bafou $2005: 12^{\text {th }}$ week

Fig. 5. Semi-variograms obtained over the 2 years of observations (2004 and 2005) at Bafou of coffee berry disease. In 2005, the trend of the curves is similar to that of the 12th week. Lag distances on the $\mathrm{x}$-axis are from the model and must be multiplied by $3 \mathrm{~m}$ to get the interval in the field. 
the end of observations. These results reflect the nonpermanent nature of CBD infection foci from one year to another in the study plots. In the case of diseases dispersed over large distances, such as rust diseases $(4,21)$, foci may be due to inoculum from outside. In the case of annual crop diseases, foci may survive from harvest residues contaminated by the pathogen. In the case of diseases with limited dispersal, such as anthracnose, especially on perennial crops, primary infection foci are not usually due to an allo-inoculum. Disease emergence is due to a primary inoculum conserved inside the plot, either in the tissues of seemingly healthy organs, or in the tissues of dead organs, such as leaves, branches, or mummified fruits. All the foci revealed by the semi-variograms were located in the plots by kriging (Figs. 6 and 7). They may have been due to heterogeneous distribution of the primary inoculum in the plot, or appear after highly conducive microclimatic conditions in particular zones of the plots. It may be, for various reasons, that such microclimates arise preferentially for several years in certain parts of plots. In that case, they would lead to the recurrent appearance of infection foci in the same places in coffee plantations, as seen over the 2 years of observations at Bafou. After harvesting, when there are no longer any berries on the coffee trees, the pathogen survives as a saprophyte in tissues not affected by the infection $(15,21)$. At the beginning of the following season, those tissues are potential sources of auto-inoculation likely to cause fresh infections on each plant in the plots. The spread of disease by foci would thus appear to be due to a combined effect, within a particular microclimate, of auto-inoculation of the plants and lateral dispersal of conidia

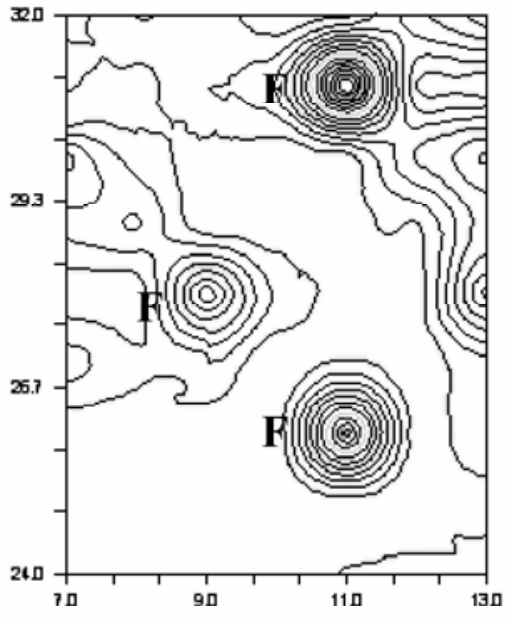

A) Santa $2003: 11^{\text {th }}$ week

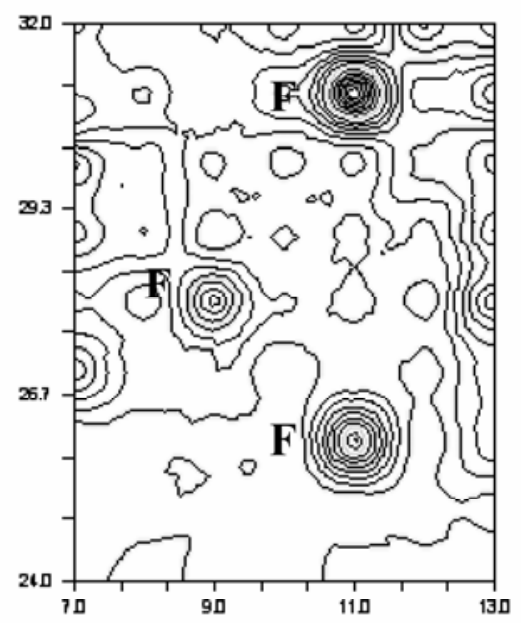

B) Santa $2003: 12^{\text {th }}$ week

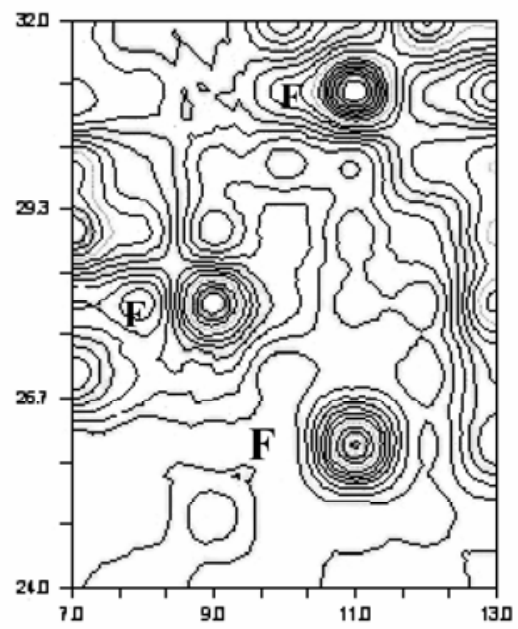

C) Santa $2003: 13^{\text {th }}$ week

Fig. 6. Coffee berry disease focus dispersal maps at Santa in 2003. F indicates the presence of an infection focus.

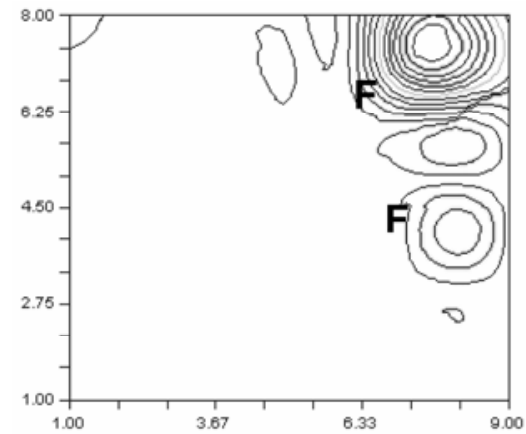

A) Bafou $2004: 8^{\text {th }}$ week

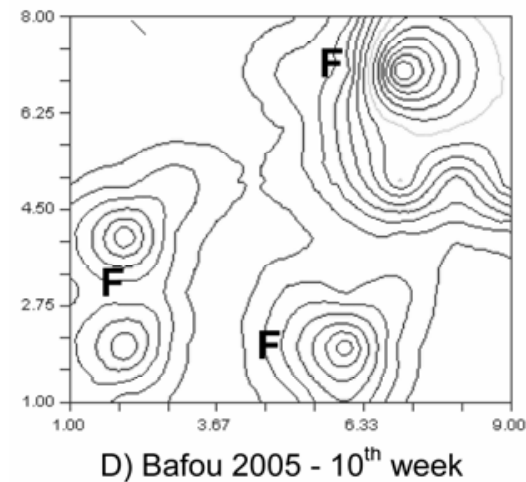

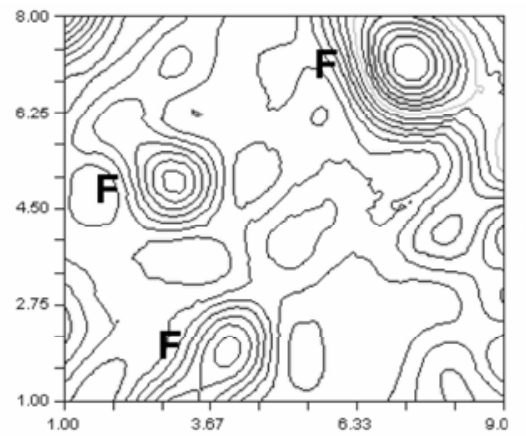

B) Bafou $2004: 9^{\text {th }}$ week

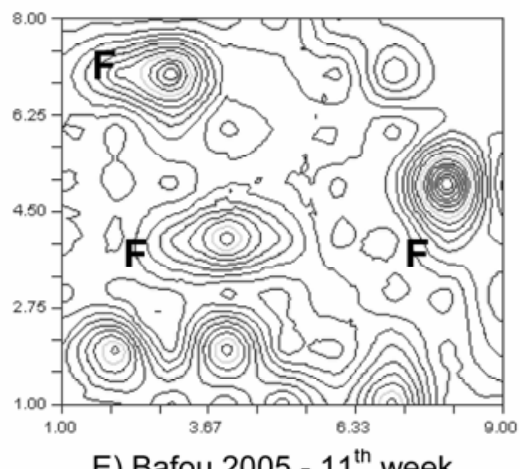

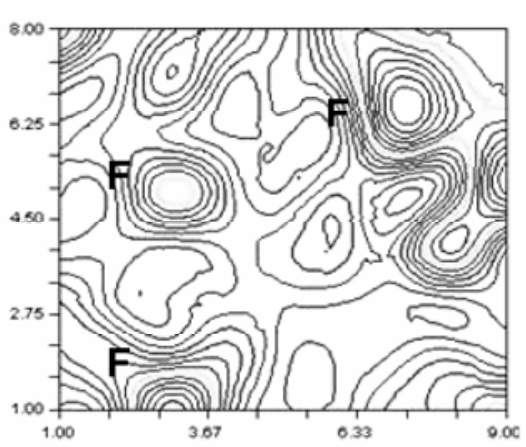

C) Bafou $2004: 10^{\text {th }}$ week

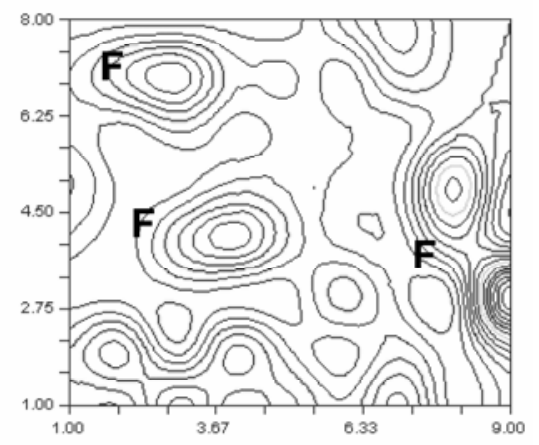

F) Bafou $2005-12^{\text {th }}$ week

Fig. 7. Coffee berry disease focus dispersal maps obtained over the 2 years of observations (2004 and 2005) at Bafou. F indicates the presence of an infection focus. 
arising from pre-existing infections. Infection foci soon fade since, in woody plants, the dissemination of diseases with low dispersal is quicker on a tree scale than within a plot. That has also been seen in the case of Monilinia fructigena infections on apple (33) or Phytophthora megakarya infections on cocoa (22).

The isotropy of the semi-variograms obtained in our study showed that CBD infection foci do not appear to follow a preferential direction within plots. That result indicates the random nature of CBD dissemination, which is mostly the result of rainfall. The spherical semi-variograms observed at Santa showed us that contamination took place in a stepwise manner between the coffee trees in the plot, which restricted the infection foci to a small number of plants. However, those of the Gaussian type, mostly found at Bafou, revealed some spatial correlations between coffee trees up to three units apart. That interval, which corresponded in reality to a distance of about $9 \mathrm{~m}$ between the trees, was an indication that the foci at that site spread to a larger number of individuals when compared to those seen at Santa. Given the main foci obtained in 2004 at Bafou (Fig. 7A to C), the spatial spread of the disease could be estimated at one unit per week, corresponding to around $3 \mathrm{~m}$ per week.

To conclude, CBD infections start from foci, whose extent and regularity depend on factors that are not yet well known. Such foci occur 1 or 2 weeks after the beginning of the disease and fade at the end of the exponential phase of the disease, shortly before the change in curve concavity. Our results suggest that studies conducted on pathogen survival at these foci will provide useful information for more effective control of the disease. Moreover, the epidemic spread curves showed that fruits should be protected from CBD before the 8th week after flowering.

\section{ACKNOWLEDGMENTS}

This study was funded by the European Union (Inco-Dev/CBD-Resist project). We thank Benoît Bertrand for logistical support, Jean P. Deumeni and the observation teams at the IRAD stations at Santa and Foumbot (Cameroon) for data gathering, Patience F. Mouen Bedimo for data entry and verification, and P. C. Musoli and L. de Lapeyre for manuscript corrections. This paper was translated into English by Peter Biggins.

\section{LITERATURE CITED}

1. Agostini, J. P., Gottwald, T. R., and Timmer, L. W. 1993. Temporal and spatial dynamics of postbloom fruit drop of citrus in Florida. Phytopathology 83:485-490.

2. Ahimera, N., Gisler, S., Morgan, D. P., and Michailides, T. J. 2004. Effects of single-drop impactions and natural and simulated rains on the dispersal of Botryosphaeria dothidea conidia. Phytopathology 94:1189-1197.

3. Arauz, L. F. 2000. Mango anthracnose: Economic impact and current options for integrated management. Plant Dis. 84:600-611.

4. Avelino, J., Willocquet, L., and Savary, S. 2004. Effects of crop management patterns on coffee rust epidemics. Plant Pathol. 53:541547.

5. Berry, D., and Cilas, C. 1994. Etude génétique de la réaction à la pourriture brune des cabosses chez des cacaoyers (Theobroma cacao L) issus d'un plan de croisements diallèle. Agronomie 14:599-609.

6. Bhatia, A., and Munkvold, G. P. 2002. Relationships of environmental and cultural factors with severity of gray leaf spots on maize. Plant Dis. 86:1127-1133.

7. Bieysse, D., Bella Manga, D., Mouen Bedimo, J. A., Ndeumeni, J. P., Roussel, V., Fabre, J. V., and Berry, D. 2002. L'anthracnose des baies une menace potentielle pour la culture mondiale de l'Arabica. Plantations, Recherche, Développement. May 2002:145-152.

8. Bouharmont, P. 1992. Sélection de la variété Java et son utilisation pour la régénération de la caféière arabica au Cameroun. Café Cacao Thé 36:247-262.

9. Charest, J., Dewdney, M., Paulitz, T., Philion, V., and Carisse, O. 2002. Spatial distribution of Venturia inaequalis airborne ascospores in orchards. Phytopathology 92:768-779.

10. Cilas, C., and Lecoustre, R. 1988. Etude spatiale de la production d'une cacaoyère suivant la méthode des variables régionalisées. Café Cacao Thé 32:299-308.

11. Denham, T. G., and Waller, J. M. 1981. Some epidemiological aspects of post-bloom fruit drop disease (Colletotrichum gloeosporioides) in citrus. Ann. Appl. Biol. 98:65-77.

12. Estrada, A. B., Dodd, J. C., and Jeffries, P. 1993. Effects of environment on the in vitro growth and development of Colletotrichum gloeosporioides isolates from the Philippines. Acta Hortic. 341:360-370.

13. Fitzell, R. D. 1981. Effects of regular applications of benomyl on the population of Colletotrichum in mango leaves. Trans. Br. Mycol. Soc. 77:529-533.

14. Fitzell, R. D., and Peak, C. M. 1984. The epidemiology of anthracnose disease of mango: Inoculum sources, spore production and dispersal. Ann. Appl. Biol. 104:53-59.

15. Gibbs, J. N. 1969. Inoculum sources for coffee berry disease. Ann. Appl. Biol. 64:515-522.

16. Griffiths, E., and Waller, J. M. 1971. Rainfall and cropping patterns in relation to coffee berry disease. Ann. Appl. Biol. 67:75-91.

17. Gupta, A. K., and Pathak, V. N. 1990. Epidemiology and management of papaya fruit rots. Summa Phytopathol.16:92-105.

18. Guyot, J., Ntawanga Omanda, E., Ndoutoume, A., Mbah Otsaghe, A.-A., Enjalric, F., and Ngoua Assoumou, H.-G. 2001. Effect of controlling Colletotrichum leaf fall of the rubber tree on epidemic development and rubber production. Crop Prot. 20:581-590.

19. Hillocks, R. J., Phiri, N. A., and Overfield, D. 1999. Coffee pest and disease management options for smallholders in Malawi. Crop Prot. 18:199-206.

20. Madden, L. V., Hughes, G., and Irwin, M. E. 2000. Coupling disease-progress-curve and time-of-infection functions for predicting yield loss of crops. Phytopathology 90:788-800.

21. Muller, R. A. 1980. Contribution à la connaissance de la phytomycocénose constituée par Coffea arabica, Hemileia vastatrix, et Hemileia coffeicola. Inst. Français Café Cacao, Bull. no. 15. Paris, France.

22. Ndoumbè Nkeng, M. 2002. Incidence des facteurs agro-écologiques sur l'épidémiologie de la pourriture brune des fruits du cacaoyer au Cameroun: contribution à la mise en place d'un modèle d'avertissements agricoles. Ph.D. thesis. Institut National Paris-Grignon, France.

23. Ntahimpera, N., Wilson, L. L., Ellis, M. A., and Madden, L. V. 1999. Comparison of rain effects on splash dispersal of three Colletotrichum species infecting strawberry. Phytopathology 89:555-563.

24. Nutman, F. J., and Roberts, F. M. 1960. Investigations on a disease of Coffea Arabica caused by a form of Colletotrichum Noack. I - Some factors affecting infection by the pathogen. Trans. Br. Mycol. Soc. 43:489-505.

25. Paul, P. A., El-Allaf, S. M., Lipps, P. E., and Madden, L. V. 2004. Rain splash dispersal of Gibberella zeae within wheat canopies in Ohio. Phytopathology 94:1342-1349.

26. Phiri, N. A., Hillocks, R. J., and Jeffries, P. 2001. Incidence and severity of coffee disease in smallholder plantations in northern Malawi. Crop Prot. 20:325-332.

27. Rapilly, F. 1991. L'épidémiologie en pathologie végétale: mycoses aériennes. Institut National de la Recherche Agronomique, Paris, France.

28. Sache, Y. 2003. L'épidémiologie. Pages 193213 in: Phytopathologie. Bases Moléculaires et Biologiques des Pathosystèmes et Fondements des Stratégies de Lutte. P. Lepoivre, ed. De Boeck Université, Gembloux, Belgium.

29. Van der Graaff, N. A. 1992. Coffee berry disease. Pages 202-230 in: Plant Diseases of International Importance, Vol. 6. A. N. Mukhopadhyay, J. Kumar, U. S. Singh, and H. S. Chaube. Prentice Hall, NJ, USA.

30. Van Leewen, G. C. M., Stein, A., Holb, I., and Jeger, J. M. 2000. Yield loss in apple caused by Monilinia fructigena (Aderh. \& Ruhl.) Honey and spatio-temporal dynamics of disease development. Eur. J. Plant Pathol. 106:519-528.

31. Van Maanen, A., and Xu, X.-M. 2003. Modelling plant epidemics. Eur. J. Plant Pathol. 109:669-682.

32. Waller, J. M. 1972. Water-borne spore dispersal in coffee berry disease and its relation to control. Ann. Appl. Biol. 71:1-18.

33. Waller, J. M., Bridge, P. D., Black, R., and Hakiza, G. 1993. Characterisation of the Coffee Berry Disease pathogen, Colletotrichum kahawae sp. nov. Mycol. Res. 97:989-994.

34. Zadocks, J. C., and Schein, R. D. 1979. Epidemiology and Plant Disease Management Oxford University Press, Oxford. 